\title{
Assessing Satellite-Based Precipitation Products to Create Flood Forecasting in the Da River Basin, Vietnam
}

\author{
Le Viet Son'1, Luong Ngoc Chung², Bui Tuan Hai', Sai Hong Anh"1,3, Nguyen Duy Quang1 \\ ${ }^{1}$ Division for Water Resources Planning for the North Region, Institute of Water Resources Planning, Hanoi, Vietnam \\ ${ }^{2}$ Board of directors, Institute of Water Resources Planning, Hanoi, Vietnam \\ ${ }^{3}$ Department of Agro-Environmental Sciences, Graduate School of Bioresource and Bioenvironmental Sciences, Kyushu \\ University, Fukuoka, Japan \\ Email: saihonganh@gmail.com
}

How to cite this paper: Son, L. V., Chung, L. N., Hai, B. T., Anh, S. H., \& Quang, N. D. (2019). Assessing Satellite-Based Precipitation Products to Create Flood Forecasting in the Da River Basin, Vietnam. Journal of Geoscience and Environment Protection, 7, 113-123.

https://doi.org/10.4236/gep.2019.711008

Received: October 4, 2019

Accepted: November 18, 2019

Published: November 21, 2019

Copyright $\odot 2019$ by author(s) and Scientific Research Publishing Inc. This work is licensed under the Creative Commons Attribution International License (CC BY 4.0).

http://creativecommons.org/licenses/by/4.0/ (c) (i) Open Access

\begin{abstract}
The Da River Basin is an international basin where available access to hydrological data is limited; it has a total basin area of $52,900 \mathrm{~km}^{2}$, about $50 \%$ of the area in which it is located, Vietnam. The Da River is the primary source of water for agriculture in 25 provinces and cities, and the primary source of drinking water for more than 30 million people in both urban and rural areas. It has huge economic and historical value. However, flood forecasting for the Da River basin has not been adequately addressed yet because of the challenge of the inconsistency, scarcity, poor spatial representation, as well as difficult access and incompleteness of the availability of ground observed rainfall data. In this research, the IFAS model has been utilized to assess the benefits of using satellite-based precipitation products to create flood forecasting for the whole research area. The results showed that the Integrated Flood Analysis System (IFAS) model was able to integrate the satellite-based precipitation products for simulating the flood event in the Da River basin. Also, the 3B42RT algorithm showed a definite improvement in reproducing the flood peak and low flow very well in the research area. These results could be used to enhance the effectiveness of flood management strategy in the basin.
\end{abstract}

\section{Keywords}

IFAS, Flood Flow, 3B42RT, and GSMaP Algorithm

\section{Introduction}

As shown in Figure 1, the Da River basin is an international river basin located 


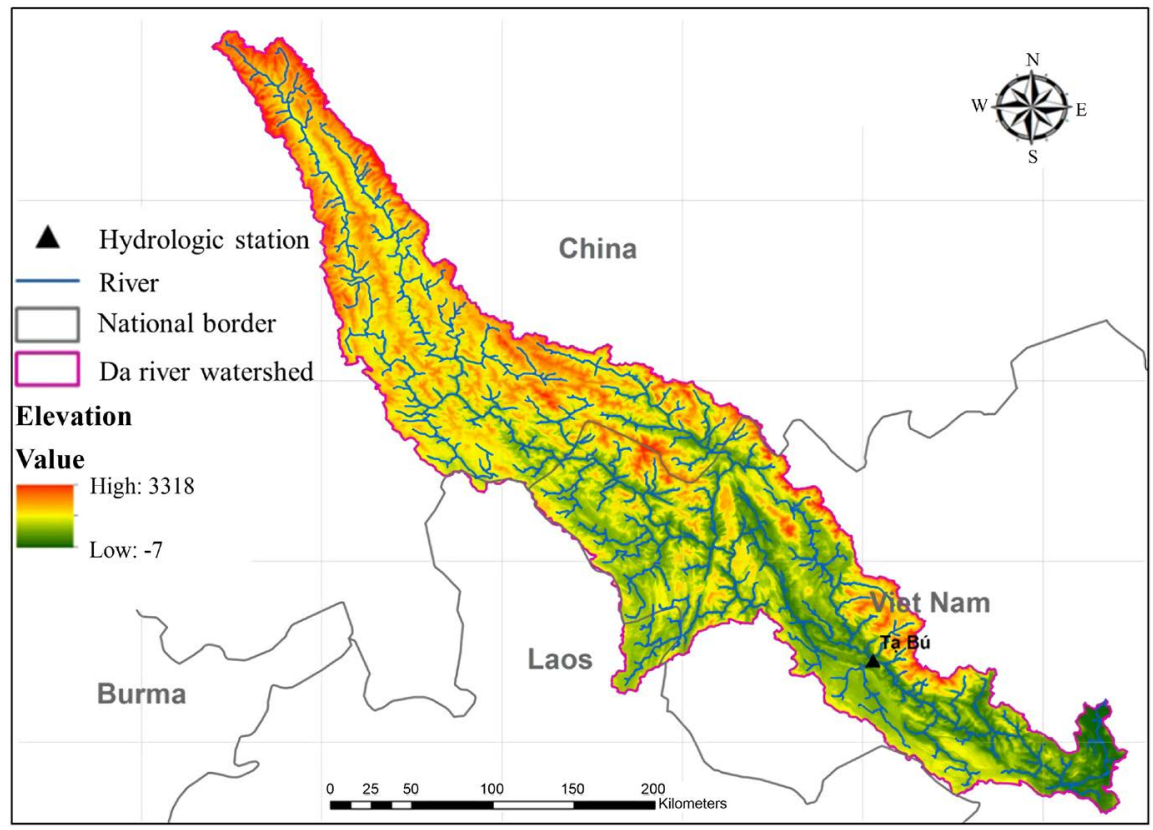

Figure 1. Location and digital elevation model (DEM) of the research area.

in Vietnam, China, and Laos. The river is one of three main upstream tributaries of the Red River, which is the largest river in northern Vietnam. The Da River has huge economic and historical value. The river is the primary water supply for agriculture in 25 provinces and cities as well as the main source of drinking water for more than 30 million people in both urban and rural areas (Vietnamese Government, 2010; IWRP, 2007). Notably, the river serves as a major water supply for hundreds of small hydroelectric power plants and large ones with total installed capacities of $6260 \mathrm{MW}$. Moreover, the flood control volume of these reservoirs accounted for 7.0 billion $\mathrm{m}^{3}$ of the total 8.45 billion $\mathrm{m}^{3}$ in the Red River system (Vietnamese Government, 2016, 2018; Son, 2019). Therefore, the Da River flow plays an important role in sustainable rural development in the basin, especially in terms of climate change, rapid urbanization, and economic development. River flooding caused by rain is a common hazard in the north of Vietnam, including the Da River basin (AHA Centre \& JICA, 2015), and it causes enormous damage to the economy and people. Until now, high-quality precipitation data has been essential to analyzing hydrological cycles in the research area. However, accurate precipitation is a great challenge, especially in the international river basin. In fact, knowledge, data, and technique-transfer in international river basins are challenging, especially between countries and regions in places where existing capacity is low (Campbell \& Barlow, 2017; Aaron et al., 1999). In previous research, Soviet experts helped to calculate annual flow, dry-season flow, and flood flow based on a statistical probability method when the biggest reservoir was built upstream of the Da River in Vietnam. Furthermore, hydrological flow calculations in this research have applied the centralized hydrological parameters with Mike 11 Nedbor-Afrstromnings-Model (NAM), Tank model, and the Hydrologic Modeling System (HMS) model and have not 
been adequately addressed to date (Vietnamese Government, 2010, 2018; IWRP, 2007). Therefore, hydrological flow calculations are indispensable to improving sustainable rural development in the research area as well as to flood risk management.

The International Centre for Water Hazard and Risk Management (ICHARM) has developed a runoff analysis model called the Integrated Flood Analysis System (IFAS) by using topographic and land-use data, and it is a toolkit for more effective and efficient flood analysis in developing countries. Moreover, utilization of satellite-based rainfall as input data is suitable to prepare flood forecasting in insufficiently gauged catchments. Also, the accuracy of the lead time of flood forecast was improved by this model and reduced the vulnerability to flooding disasters (Icharm, 2014; Chow \& Jamil, 2017). This helped basin managers respond to damage from floods due to heavy rain.

The main aim of this study was to utilize the IFAS model to assess, propose, and approach satellite-based precipitation products to create flood forecasting for the Da River basin where there is an insufficiently gauged catchment. Satellite precipitation products can be derived from many different sensors. In this research, the Global Satellite Mapping of Precipitation (GSMaP) algorithm was used with various observation satellite Geostationary (GEO IR). Also, the Tropical Rainfall Measuring Mission (TRMM) -3B42RT algorithm was utilized with data from the modern satellite-borne precipitation sensors to compare the results.

\section{Materials and Methods}

\subsection{Study Area}

Figure 1 depicts the location of the Da River basin, and it is an international river basin with a total area of $52,900 \mathrm{~km}^{2}$, in which the areas located in Vietnam, China, and Laos are $26,826 \mathrm{~km}^{2}, 24,974 \mathrm{~km}^{2}$, and $1100 \mathrm{~km}^{2}$ respectively (11). The Da River area is a part of the Red River system, and the Da River flow closes to $50 \%$ of the total flow of the Red River system. The topographic map, river channel network, land use, soil type, and geology data used in this study were obtained from the global GIS database and satellites (Chow \& Jamil, 2017).

\subsection{Hydrology Model}

The IFAS (Integrated Flood Analysis System) model is used herein to simulate flood flows. IFAS used the theoretical tank model and Manning's law, Darcy's law, and kinematic wave method (Icharm, 2014; Sugawara et al., 1974; Fukami et al., 2014). Schematic diagrams of the tank model are shown as follows:

\section{Surface Tank Model}

Figure 2 shows the diagram of the surface tank model, and it is used to divide the rainfall to infiltration flow, surface outflow, and rapid intermediate outflow.

$Q_{0}$ is the infiltration flow. $Q_{s f}$ is the surface outflow. $Q_{r i}$ is the rapid intermediate outflow. $h$ is the water height for the tank. $S_{A}$ is the height from which 


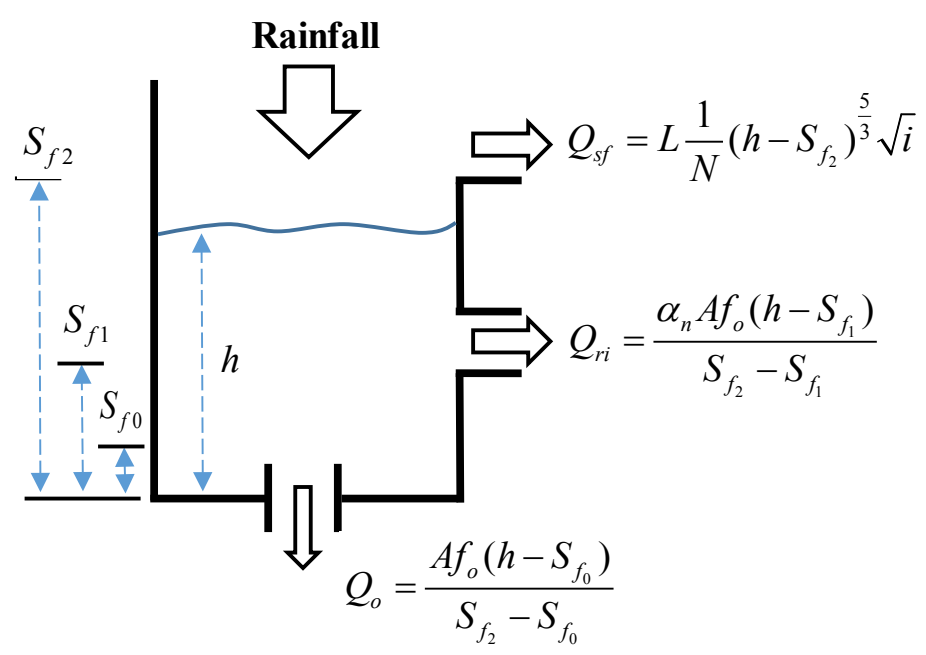

Figure 2. Diagram of the surface tank model.

saturated excess overland flow occurs. $S_{A}$ is the height from which rapid subsurface storm flow occurs. $S_{0}$ is the height where ground infiltration occurs. $f_{0}$ is the vertical hydraulic conductivity. $N$ is the surface roughness coefficient. $L$ is the mesh length. $\alpha_{n}$ is the rapid unsaturated subsurface flow regulation coefficient.

\section{Aquifer Tank Model}

Figure 3 shows the diagram of the aquifer tank model. The unconfined and confined groundwater flow and groundwater loss were shown as follows:

Where, $Q_{i n}$ is the inflow from infiltration mode; $h$ is the water height of model; $Q_{g 1}$ is the unconfined aquifer outflow; $S_{g}$ is the height from which unconfined aquifer outflow occurs; $Q_{g 2}$ is the confined aquifer outflow/base flow; $Q_{g_{-} \text {loss }}$ is the unaccountable aquifer loss; $A_{u}$ and $A_{g}$ being the coefficients used to calculate unconfined and confined aquifer outflows.

\section{Subsurface Tank Model}

The subsurface tank model is used to simulate the low flow conditions as well as long-term periods (Figure 4).

where $Q_{i n}$ is flow coming from the surface tank, $Q_{S 1}$ is unsaturated lateral flow/slow subsurface stormflow, $Q_{S 2}$ is unsaturated vertical flow/slow subsurface stormflow, $D$ is total water height for unsaturated tank, $h$ is water height for this tank, $\theta$ is soil moisture content $(=h / D), S_{S}$ is height when $\theta=\theta_{S}$, soil moisture is equal to soil moisture at saturation and $\theta_{S}=S_{S} D, K_{X}$ is horizontal hydraulic conductivity at $\theta_{S}, K_{Z}$ is vertical hydraulic conductivity at $\theta$.

\section{River Course Tank Model}

Figure 5 shows the diagram of the river course tank model, in which $Q_{i n}$ is the inflow through the upstream surface and groundwater tanks; $Q_{r}$ is an outflow from the river course and calculated by Manning's formula; $h$ is water height for the tank; B is the breadth of the river course. The river course breadth is calculated according to the Resume Law as follows:

$$
B=c A s(c \text { and } s \text { are constants, generally } s<1) .
$$




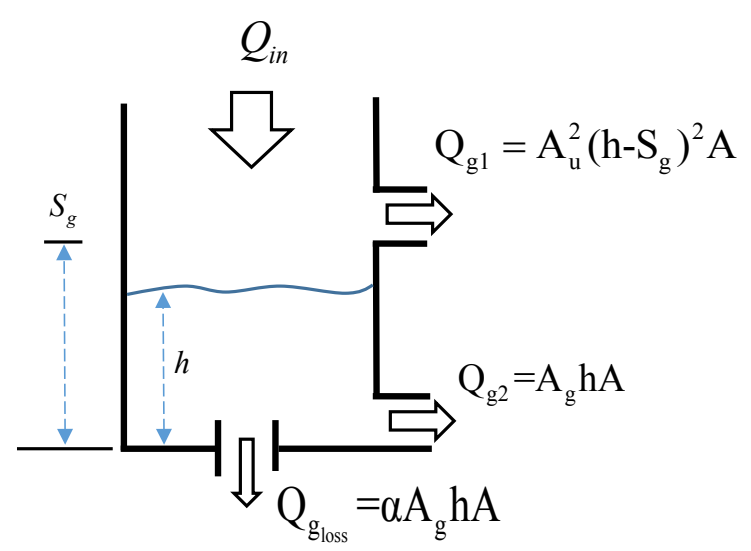

Figure 3. Diagram of the aquifer tank model.

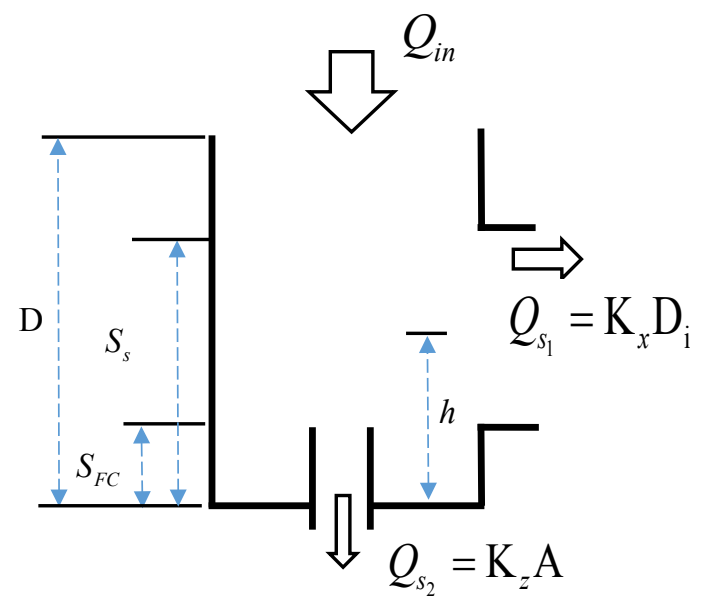

Figure 4. Diagram of the subsurface tank model.

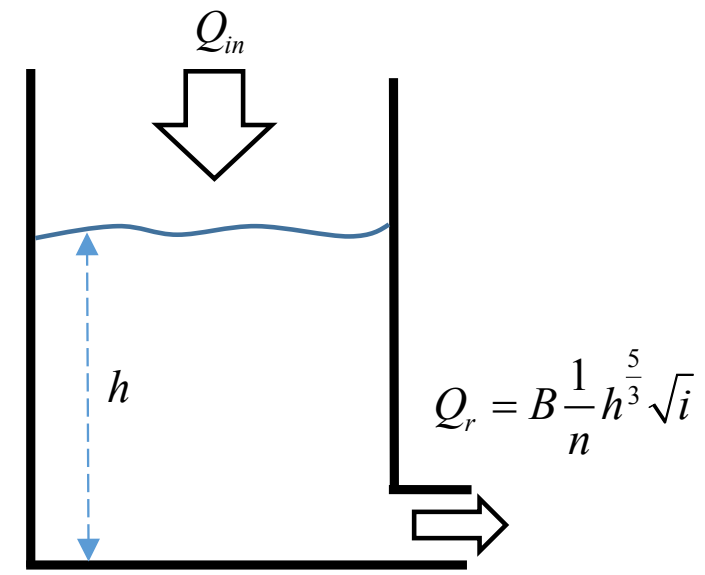

Figure 5. Diagram of the river course tank model.

Because the model considers runoff, its influence on the river course outflow is omitted.

For river course tank in cell type 3 , the river routing method is the kinematic wave method using the difference method as follows: 


$$
\frac{\partial Q}{\partial t}+C \frac{\partial Q}{\partial x}=0 \text { with } C=\frac{d Q}{d A}
$$

$C$ is the kinematic wave celerity.

\subsection{Model Setup}

To set up the IFAS model for the Da river basin, land use was categorized into four classes, including forest, grass and shrubland, agriculture, and built-up land, in which the largest part of the basin is covered by forest (Figure 6). Digital Elevation Model (DEM), land use, soil, and geology data are imported from global data. Global data sets are relevant to flood analysis, which can be used to create a run-off analysis model and estimate parameters for the river basin. The details of elevation were determined from the DEM data in this research area. Also, the GTOPO30 with a $1 \times 1 \mathrm{~km}$ resolution was used to create the catchment boundary, river network, and sub-catchments for the Da basin (Figure 1).

\subsection{Assessing Method}

The accuracy of the model was assessed using the Nash-Sutcliffe model efficiency coefficient (NASH) and Relative error when the flood reached its peak as follows:

1) The Nash-Sutcliffe model efficiency coefficient (NASH) is a normalized

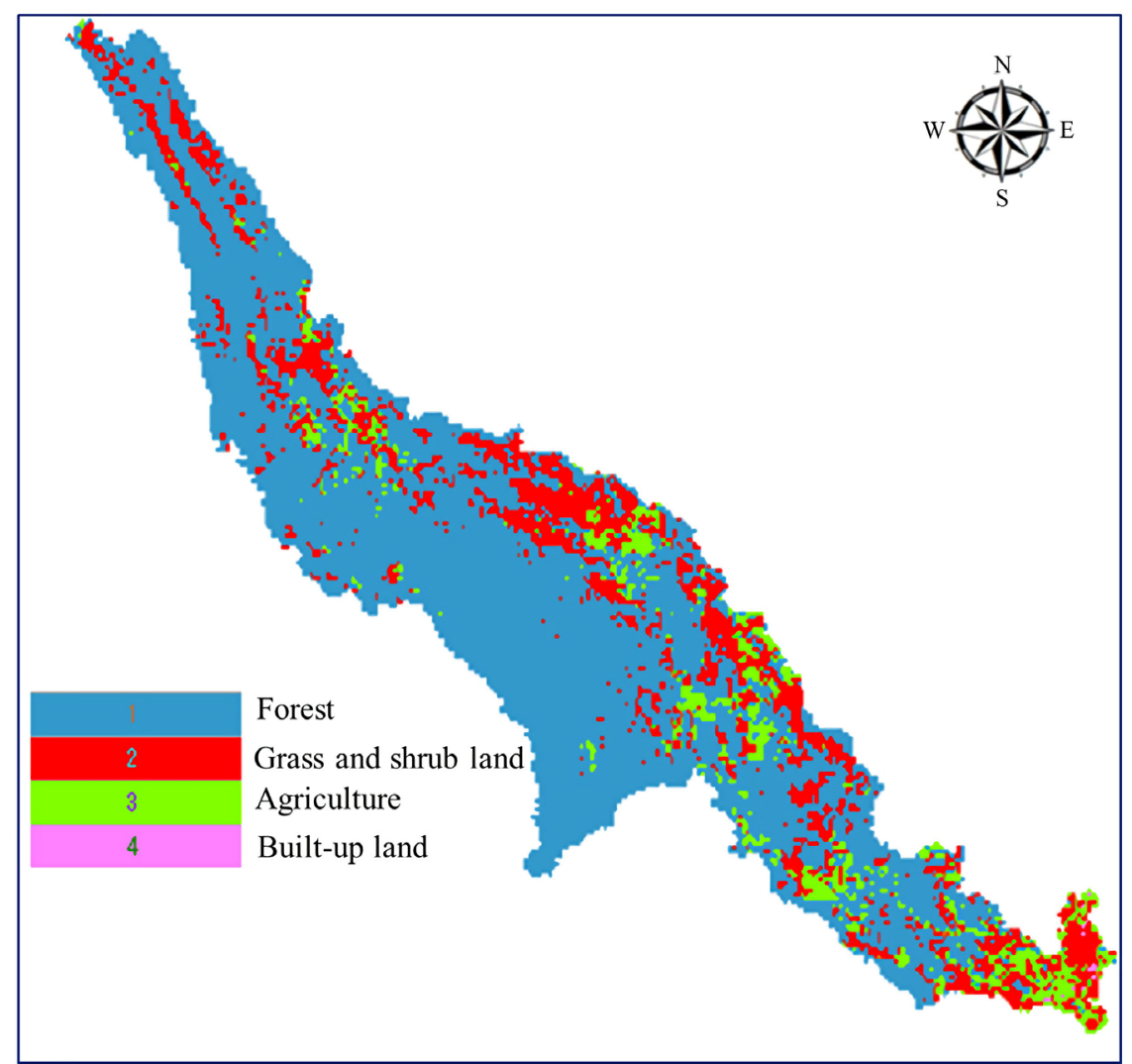

Figure 6. The land use was categorized into 4 classes, including forest, grass, shrubland, agriculture, and built-up land. 
statistic that determines the relative magnitude of the residual variance as noise compared to the measured data variance as information.

$$
\mathrm{NASH}=1-\frac{\sum\left(Q_{c a l}-Q_{o b s}\right)^{2}}{\sum\left(Q_{o b s}-Q_{o b s a v e r}\right)^{2}}
$$

where $Q_{c a l}$ Simulated discharge $\left(\mathrm{m}^{3} / \mathrm{s}\right) ; Q_{o b s}$ Observed discharge $\left(\mathrm{m}^{3} / \mathrm{s}\right) ; Q_{o b s a v e r}$ Average observed discharge $\left(\mathrm{m}^{3} / \mathrm{s}\right)$

2) The relative error of the peak flood.

$$
\Delta Q \%=\frac{Q_{\max o b s}-Q_{c a l}}{Q_{\max o b s}}(\%)
$$

\section{Results and Discussion}

In order to propose satellite precipitation products for the Integrated Flood Analysis System model (IFAS) to simulate flood streamflow discharges for the Da River, two important algorithms were used. First, the precipitation profiles from the Global Satellite Mapping of Precipitation (GSMaP) algorithm were utilized. Then, the precipitation profiles from the Tropical Rainfall Measuring Mission (TRMM) Multi-Satellite Precipitation Analysis Real-Time (3B42RT) were used to compare the results.

\subsection{GSMaP Algorithm}

The Global Satellite Mapping of Precipitation (GSMaP) project has been developed to provide precipitation map algorithms, including microwave radiometer/sounder algorithms from various observation satellites like GEO IR, and it is also an integrated algorithm producing hourly global precipitation maps (Okamoto et al., 2005; Kubota et al., 2007; Falck et al., 2015). In this research, the capacity of the satellite-based products to estimate flood events were evaluated from July 23rd to August 22nd, 2002. Three major floods happened during that period in the Da River Basin, and heavy rainfall in the upstream region caused these flood events.

Figure 7 shows the observed and calculated stream flows at the Ta Bu Station. These results indicated that GSMaP underestimated monsoon rainfall averages over the research area throughout the flood period and reflected the incompetence of GSMaP to detect extreme precipitation, leading to low accuracy in simulating flood events in this research area. In more detail, when the first flood reached its peak on July 26th, 2002-12:00 PM, the streamflow discharges at the $\mathrm{Ta} \mathrm{Bu}$ Station were $9350 \mathrm{~m}^{3} / \mathrm{s}$ and $11,100 \mathrm{~m}^{3} / \mathrm{s}$ for calculated and observed profiles, respectively. The streamflow discharge difference was $1750 \mathrm{~m}^{3} / \mathrm{s}$. In the second flood event on August 2nd, 2002-5:00 AM, the difference was much higher with $5750 \mathrm{~m}^{3} / \mathrm{s}$. Besides, in the third flood event, when the flood reached its peak on August, 12th, 2002-1:00 AM, the observed and calculated discharge profiles were $13,900 \mathrm{~m}^{3} / \mathrm{s}$ and $7360 \mathrm{~m}^{3} / \mathrm{s}$, respectively. These results once again showed the incompetence of GSMaP in predicting precipitation in this research 


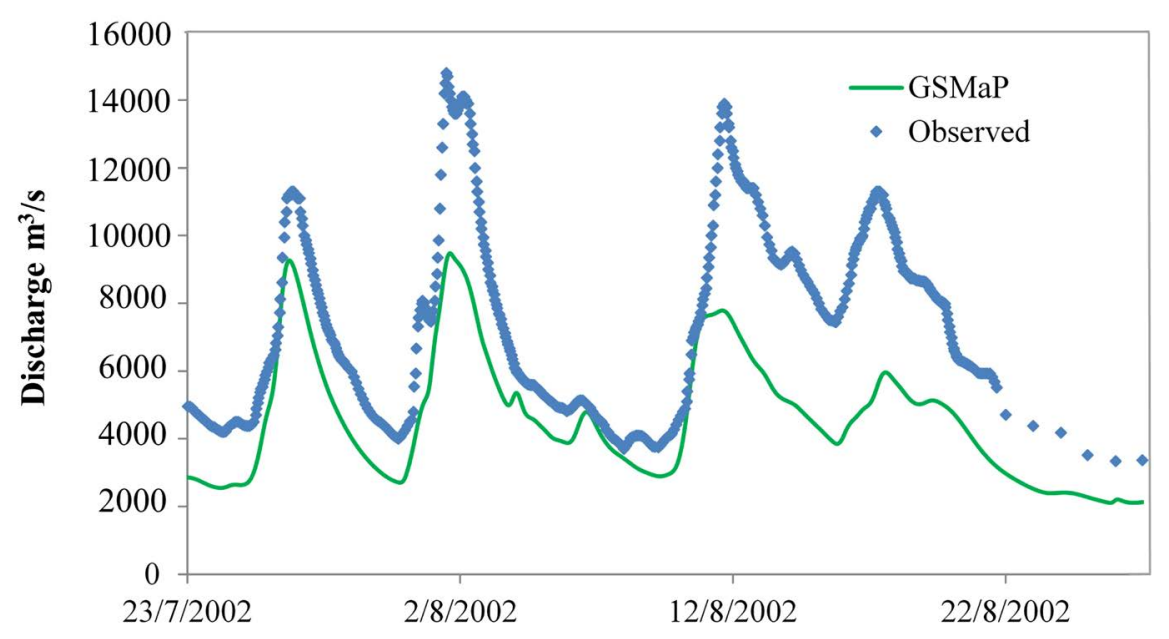

Figure 7. The observed and calculated streamflow discharges at the Ta Bu Station.

area. It is noted that the GSMaP rainfall product used in this study is GSMaP MVK product, which is the combination of low earth orbit multi-satellite microwave radiometer data and infrared radiometer on geostationary orbit. The brightness temperature at microwave frequencies as the main input of the GSMaP_MVK system was converted into precipitation data. The reason for the underestimation of rainfall by GSMaP product may lie in the fact that the current algorithm of microwave radiometer did not include the topographical effect and the brightness temperature from the microwave radiometer had directly underestimate relation with precipitation (Setiawati \& Miura, 2016).

\subsection{TRMM 3B42RT}

The Tropical Rainfall Measuring Mission (TRMM) Multi-satellite Precipitation Analysis in real-time (3B42RT) provides a good estimate of quasi-global precipitation from modern satellite-borne precipitation sensors (Tekeli \& Fouli, 2016; Huffman et al., 2007). The three-hourly 3B42RT images covering two periods, from July 23rd to August 22nd, 2002 and from July 1st to July 31st, 2006, are used herein to compare the observed and calculated streamflow discharges at the Ta Ba Station. During the first period, three flood events occurred, and one flood event was recorded during the second period.

In 2002, the results demonstrated good correlation in terms of the observed and calculated streamflow discharges at the $\mathrm{Ta} \mathrm{Bu}$ station from July 23rd to August 22nd, 2002 (Figure 8), and 3B42RT performed better GSMaP in the research area. In more detail, the NASH coefficient and relative errors are $0.71 \%$ and $1.0 \%$, respectively, and they show good agreement (Table 1). In the first flood event, which reached its peak at 00:00 AM on July 27th, 2002, the observed and calculated streamflow discharges were $11,100 \mathrm{~m}^{3} / \mathrm{s}$ and $12,914 \mathrm{~m}^{3} / \mathrm{s}$, respectively. However, there were small differences in the streamflow discharge values of the second and third flood events of approximately $905 \mathrm{~m}^{3} / \mathrm{s}$ and $675 \mathrm{~m}^{3} / \mathrm{s}$.

In 2006, the result was also in close agreement with the NASH of 0.86 and the relative error of $2.0 \%$. Figure 9 shows a high correlation between the observed 
Table 1. The NASH coefficient and relative error when the flood reached its peak.

\begin{tabular}{cccc}
\hline No & Period & NASH & $\Delta$ Qmax (\%) \\
\hline 1 & July 23rd to August 22nd, 2002 & 0.71 & 1.0 \\
2 & July 1st to July 31st, 2006 & 0.86 & 2.0 \\
\hline
\end{tabular}

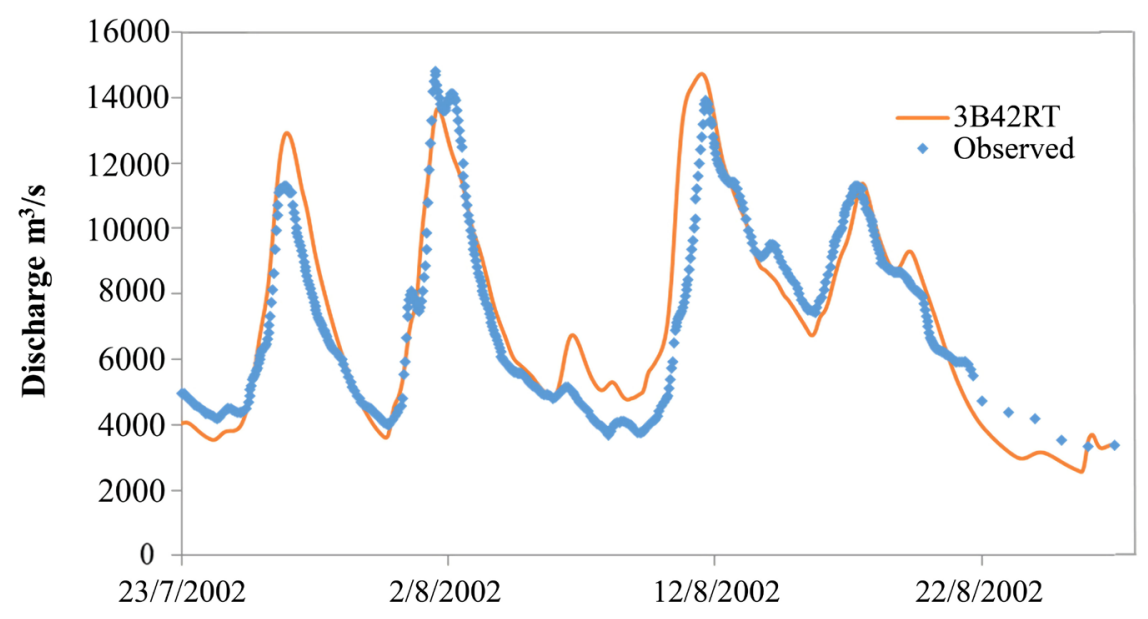

Figure 8. Observed and calculated river discharge at Ta Bu Station from July 23rd to August 22nd, 2002.

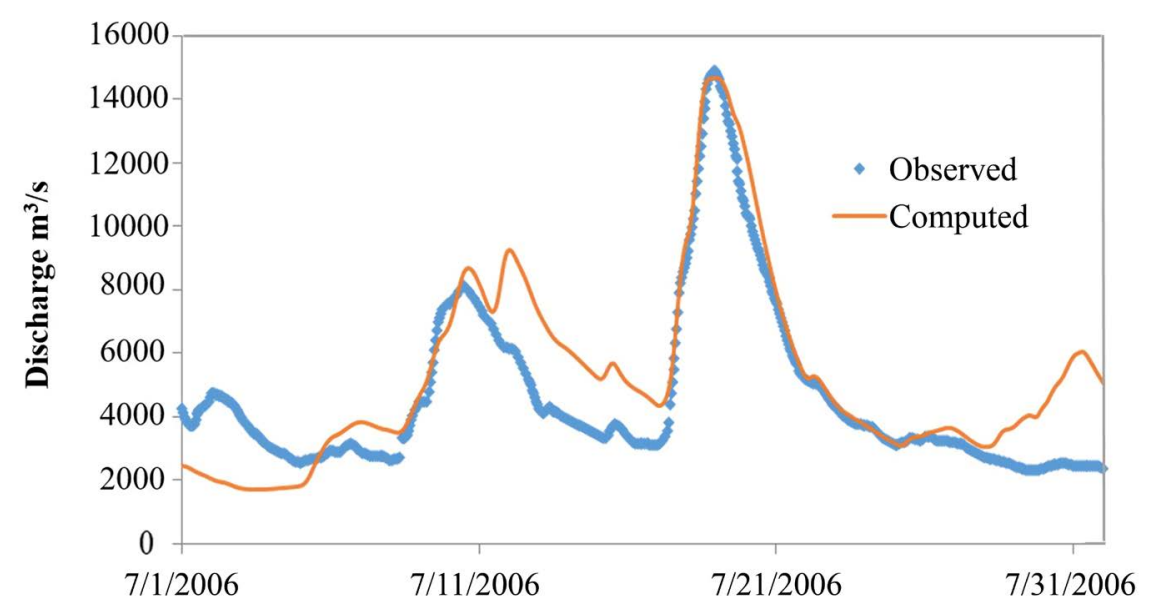

Figure 9. Observed and calculated river discharge at Ta Bu Station from July 1st to July 31st, 2006.

and calculated profiles. When the flood reached its peak on July 18th, 2006, the difference between the observed and calculated streamflow discharge values at the $\mathrm{Ta} \mathrm{Bu}$ Station was roundly $150 \mathrm{~m}^{3} / \mathrm{s}$.

Obviously, 3B42RT showed a clear improvement in reproducing the flood peak and low flow very well in the research area, which is much higher than that of GSMaP.

\section{Conclusion}

This study has encouraged the use of the IFAS model to create flood forecasting 
in the Da River basin using satellite-based precipitation products. The inconsistency, scarcity, poor spatial representation, as well as difficult access and incompleteness of the availability of ground observed rainfall data in the Da River make it necessary to adopt earth observation data products to pursue hydrological modeling for the Da River Basin. Also, a comprehensive assessment of satellite-based precipitation products for the research area has been presented. The IFAS model was used for the first time in the research area with the global GIS database and satellites in high resolution.

These results indicated that the Integrated Flood Analysis System (IFAS) was able to integrate the satellite-based precipitation products for simulating the flood event in the Da River basin. Here, 3B42RT showed a clear improvement in reproducing the flood peak and low flow very well in the research area, which is much higher than that of the GSMaPalgorithm. The results demonstrated a good correlation in comparison to the observed and calculated streamflow discharges at the $\mathrm{Ta} \mathrm{Bu}$ Station with the 3B42RT algorithm. Although the calculated satellite rainfall data from the 3B42RT algorithm was performed well in flood forecasting in the Da River basin, future research still needs to improve the accuracy of the model.

\section{Acknowledgments}

The authors appreciate the funding support and providing the data of the National-level science research Project "Research on flood risks, propose preventive and adaptive solutions for densely populated areas and northern mountains urban".

\section{Conflicts of Interest}

The authors declare no conflicts of interest regarding the publication of this paper.

\section{References}

Wolf, A. T., Natharius, J. A., Danielson, J. J., Ward, B. S., \& Pender, J. K. (1999). International River Basins of the World. International Journal of Water Resources Development, 15, 387-427. https://doi.org/10.1080/07900629948682

AHA Centre (ASEAN Coordinating Centre for Humanitarian Assistance on Disaster Management), JICA (Japan International Cooperation Agency) (2015). Natural Disaster Risk Assessment and Area Business Continuity Plan Formulation for Industrial Agglomerated Areas in the ASEAN Region-Country Report-Vietnam.

Campbell, \& Barlow, C. (2017). Ch. 16: Knowledge Transfer in International Water Resource Management-Six Challenges (pp. 293-303). Cambridge, MA: Academic Press. https://doi.org/10.1016/B978-0-12-810523-8.00017-3

Chow, M. F., \& Jamil, M. M. (2017). Review of Development and Applications of Integrated Flood Analysis System (IFAS) for Flood Forecasting in Insufficiently-Gauged Catchments. Journal of Engineering and Applied Sciences, 12, 9210-9215.

Falck, A. S., Maggioni, V., Tomasella, J., Vila, D. A., \& Diniz, F. L. R. (2015). Propagation of Satellite Precipitation Uncertainties through a Distributed Hydrologic Model: A Case 
Study in the Tocantins-Araguaia Basin in Brazil. Journal of Hydrology, 527, 943-957. https://doi.org/10.1016/j.jhydrol.2015.05.042

Fukami, K., Sugiura, Y., Magome, J., \& Kawakami, T. (2014). Integrated Flood Analysis System: IFAS Ver. 2.0 User's Manual (pp. 238-259). Japan PWRI-Technical Note Inc.

Huffman, G. J., Adler, R. F., Bolvin, D. T., Gu, G., Nelkin, E. J., Bowman, K. P., Wolff, D. B. et al. (2007). The TRMM Multisatellite Precipitation Analysis (TMPA): Quasi-Global, Multiyear, Combined-Sensor Precipitation Estimates at Fine Scales. Journal of Hydrometeorology, 8, 38-55. https://doi.org/10.1175/JHM560.1

IWRP (2007). Hydrological Report, Integrate Water Resources Management in the Red River Basin. Hanoi: Institute of Water Resources Planning. (In Vietnamese)

Kubota, T., Shige, S., Hashizume, H., Aonashi, K., Takahashi, N., Seto, S., Hirose, M., Takayabu, Y. N., Nakagawa, K., Iwanami, K., Ushio, T., Kachi, M., \& Okamoto, K. (2007) Global Precipitation Map Using Satellite-Borne Microwave Radiometers by the GSMaP Project: Production and Validation. IEEE Transactions on Geoscience and Remote Sensing, 45, 2259-2275. https://doi.org/10.1109/TGRS.2007.895337

Okamoto, K., Iguchi, T., Takahashi, N., Iwanami, K., \& Ushio, T. (2005). The Global Satellite Mapping of Precipitation (GSMaP) Project. In Proceedings of IGARSS (pp. 3414-3416). New Jersey: Institute of Electrical and Electronics Engineers.

Setiawati, M., \& Miura, F. (2016). Evaluation of GSMaP Daily Rainfall Satellite Data for Flood Monitoring: Case Study-Kyushu Japan. Journal of Geoscience and Environment Protection, 4, 101. https://doi.org/10.4236/gep.2016.412008

Son, L. V. (2019). Assessing the Situation of Water Supply and Propose Solutions to Improve the Efficiency of Additional Water Supply from Hydropower Reservoirs for Winter-Spring Rice Cultivation in the Midland and Northern Delta Regions. Hanoi: Institute of Water Resources Planning. (In Vietnamese)

Sugawara, M. et al. (1974). Tank Model and Its Application to Bird Creek, Wollombi Brook, Bikin River, Kitsu River, Sanaga River and Nam Mune (pp. 1-64). Research Note of the National Research Center for Disaster Prevention, No. 11.

Tekeli, A. E., \& Fouli, H. (2016). Evaluation of TRMM Satellite-Based Precipitation Indexes for Flood Forecasting over Riyadh City, Saudi Arabia. Journal of Hydrology, 541, 471-479. https://doi.org/10.1016/j.jhydrol.2016.01.014

The International Centre for Water Hazard and Risk Management (ICHARM) (2014). IFAS Version 2.0 Technical Manual. Tsukuba-shi: Public Works Research Institute.

Vietnamese Government (2018). Vietnam Statistical Yearbook 2018. Hanoi: General Statistics Office. (In Vietnamese)

Vietnamese Government (2010). 1989/QD-TTg. Interprovincial River Basins of Vietnam. (In Vietnamese)

http://vanban.chinhphu.vn/portal/page/portal/chinhphu/hethongvanban?class_id=1\& $\underline{\text { mode }=\text { detail } \& \text { document_id }=97581}$

Vietnamese Government (2016). 257/QD-TTg Planning for Flood Prevention and RedThaiBinh River Dike System. Vietnam. (In Vietnamese)

http://vanban.chinhphu.vn/portal/page/portal/chinhphu/hethongvanban?class_id=2\& $\underline{\text { mode }=\text { detail\&document_id }=183476}$ 